\title{
Achieving the innovative edge in technology, engineering design, and entrepreneurship
}

\author{
Robert M. Pech
}

\author{
Correspondence: robert.pech@ \\ kustar.ac.ae \\ Khalifa University of Science, \\ Technology and Research, PO Box \\ 127788, Abu Dhabi, United Arab \\ Emirates
}

\begin{abstract}
Disruptive and radical innovations can lead to achieving a competitive edge in technology, design engineering, and entrepreneurship. Likewise, entrepreneurship can encourage more innovation. This article highlights the inter-relationships between these forces and how one can inform and action the others. By examining diverse industries such as Hewlett-Packard; Little Swan of China; Rip Curl, the surfing company of Australia; and others as case studies, and numerous other practical examples appropriately selected from across the last century, the role of technology and design in advancing products and services in the commercial arena is exemplified and demonstrates that there are common patterns over time in which technological and managerial advancements play unique and vital roles in driving markets. The article also identifies the key characteristics of disruptive technologies and those of successful innovative engineers, as well as those of successful entrepreneurs in the field of technology and engineering by examining their approaches and methods to serve as catalysts for future innovators who set their sights on starting up their own venture.
\end{abstract}

Keywords: Disruptive innovation, Design engineering, Closed and open innovation, New venture, Intellectual property, Niche, Dominant model, Social (or philanthropic) entrepreneurship

\section{Background}

The intention of the article is to provide a discursive overview of the relationship between technology, design, and entrepreneurship because there is a high failure rate in that complex relationship. It highlights those in which the elements in this relationship have integrated successfully. So, this work couples theoretical principles with commercial implementation as an incitement to further successful innovation and entrepreneurship in the future through positive exemplification. Innovation and entrepreneurship are primarily about practical outcomes, and innovation, in particular, is an elusive entity. Its nature, forms of implementation, and its future cannot be defined and calculated only through theory and calculation. This work provides particular emphasis on practice and outcomes, because followers of innovation and entrepreneurship often want to know "who," "what," and "how," as well as "why". Bygrave and Zacharakis (2008) inform us that according to a survey conducted by ACNielsen

\section{Springer}


International Research in July 2005, 58 \% of Americans say they have wished to start a business and be their own boss. But, according to Alfred Nucci at the US Census Bureau, $81 \%$ survive for 1 year, $65 \%$ for 2 years, $40 \%$ for 5 years, and only $25 \%$ for 10 years (p. 3). For innovation and entrepreneurship to combine successfully and sustainably, it is useful to examine the innovator-and-entrepreneur connection by demonstration of exponents and their methods.

\section{Results and discussion}

\section{Disruptive innovations and their impact in relation to commercialization}

Disruptive innovation is a potent form of radical innovation in the fields of technology and entrepreneurship. This form of innovation, first identified and so called by Christensen and Raynor (2003), has a number of characteristics which make it valuable. Firstly, like radical innovation, it represents a breakthrough in technology rather than merely a small improvement. It is likely to radically alter people's perception of the service such a product can provide. Usually by means of enhanced technology, it is a product that is cheaper to buy and service easier to use and produces better results. As such, it has a propensity to push its competitors and predecessors aside or eventually banish them as well as the companies that produced them from the market altogether. By 2009, Dyer et al. proposed that the ability to think creatively "comes one-third from genetics; but two-thirds of the innovation skill set comes through learning - first understanding a given skill, then practicing it, experimenting, and ultimately gaining confidence in one's capacity to create" (p. 3). To that end, Hang et al. (2011) designed an assessment framework to better identify the characteristics and holistic success factors for disruptive innovation [...] grouped under market positioning, technology, and other favorable drivers" (p. 4). The originality and value of their work was to attempt to devise a method to gauge whether a disruptive innovation assessment could indeed be used to provide a prediction about the success of an innovation. However, as Leavy and Sterling pointed out, market research is difficult to implement in a disruptive ecosystem because those markets do not yet exist, and so they cannot be measured for potential investment (2010, p. 8).

Leavy and Sterling quote Scott Anthony, President of Innosight, in believing that where markets have constraints, disruptive innovation can be most prolific when "there are people who lack the skills, wealth, access or time to solve pressing problems in their lives" (Ibid. p. 7). Anthony opines furthermore that "The best way to develop disruptive capabilities is to start small and learn as you go". (Ibid. p. 8), and this is corroborated by Cowden and Alhorr (2013) whose research led them to conclude that "For MNEs that pursue disruptive innovations, more [of them] will be discovered in subsidiaries than in the [obviously larger] parent" (p. 363).

Kaplan (2012) and Mazzucato (2015, p. 61) have both pointed out that management needs to upgrade its way of creative thinking and operating because "bureaucratic institutions actively inhibit [innovation]". Risk taking is endemic to creating a disruption. Christensen cites the example of the photocopier (p. 57). Xerox, the long-established and reputable manufacturer of copiers, had a principal design that made the machines so large that they occupied considerable space in any office; furthermore, they were expensive to buy, performed indifferently, and needed regular maintenance. One problem 
with the technology was that the drum inside accumulated electromagnetic charges, so that the paper on which the image was being reproduced frequently clung to the drum thereby jamming the machine. Canon of Japan "disrupted" this technology when they successfully designed a copier small enough to fit on a desktop, being cheaper to buy and service because the operators could replace toner themselves now that this came in convenient cartridges and the problem of jamming paper was largely, although not entirely, eliminated (Christensen and Raynor 2003).

Ursula Burns, CEO of Xerox Corporation, talked about the "American spirit [...] impatient, bold and agile" (Shapiro 2013). But, disruption is universal and not confined to particular regions. Another example includes e-mail replacing "snail" mail, the physical letter in an envelope-disruptive to such an extent that in New Zealand, for example, a country with a small 4.5 million population, almost 40,000 postal delivery agents have been made redundant in stages during the last 10 years as e-mail and other forms of social media have become prevalent. The printed book has also been disrupted: websites and Kindle, a product from Amazon Inc., have meant that books and other lengthy documents can now be downloaded at a fraction of the cost of their equivalent in print. While print is not obsolete, this disruptive technology has had a substantial impact on the market for readers, particularly since Kindle has reduced the cost of a wide variety of written materials by as much as two thirds.

However, the meaning of disruptive technology can also encompass a broader meaning. John Seely Brown, for example, enlarges its definition to literally refer to this kind of innovation disrupting people's lives, not just the operational practices of a disruptive technology's competitors. He comments that it "actually changes social practices - the way we live, work and learn. Really substantive innovation [...] is quite disruptive, drastically altering social practices" (Chesbrough 2003, p. ix). Almost a decade later, Seely Brown expanded on this: "[creators try] to mobilize the acceptance of an idea within an organization or community. The next step to acceptance and community engagement is providing a way for the community to envision how this innovation might affect them" (Denning and Dunham 2010, p. x). This may involve adjustments and change to conventional practices of all kinds, some of which involve a measure of risk and an even greater measure of faith in the new technologies involved. For example, in medicine, surgery can now be conducted endoscopically, meaning that surgical equipment and a camera can be inserted into the human body through a very small incision. The advantage is that large wounds used to take much longer to heal and were more subject to infection. Here, disruption is to hospital procedures and equipment, ward recuperation times which affects scheduling, and the increase in the number of patient surgeries which a hospital can accommodate. From here, it was only a short step to have complex surgeries facilitated robotically via distance by remote control.

Disruptive technologies have the following characteristics in summary:

1. They comprise one or more substantial advance(s) in technology and engineering design often achieved through forms of digitization and/or miniaturization.

2. Are highly cost-effective.

3. They intrigue users through novelty value as much as productive value.

4. Are convenient to use.

5. Are simple to operate. 
6. Displace their predecessors over a relatively short time because users identify their advantages readily.

7. But, where special training is involved, the process of adoption may take longer, for example with the practice of endoscopic surgery. However, its near-universal adoption is eventually a certainty.

\section{Closed and open-source innovation}

Companies have found that methods of innovation can present problems and difficulties. Technology and commerce are two intensely competitive fields, and each of them vies for international recognition and market leadership. As a result, companies in the 1980s and 1990s acted on a model of ownership. To a large extent, they still do. They believed that anything they could innovate had to come from inside the company itself and that it should be protected as its very own intellectual property by means of patents and trademarks in case any competitor or disruptor stole the march. Chesbrough refers to this as "Closed Innovation" (2003). The problem with this early system was that it imposed its own limitations. It relied exclusively on in-house expertise, took time to organize and develop, and was costly to produce and protect. It harked back to the early 1980s model when Apple's Steve Wozniak and Steve Jobs went to great lengths to maintain complete secrecy about the Apple II's operating platform. Licensing the platform would instead have been a lucrative alternative in order to expand their brand. In the twenty-first century, intellectual property controversies have also resulted in expensive and antagonistic court proceedings between successive technological advances between Samsung and Apple encased in the questions "Who owns what? Who copied whom?"

On the other hand, as time marched on and global competition became intense, companies realized that the closed innovation model should largely be discarded in favor of open-source innovation. In this paradigm, or mode of thinking, intellectual property is shared between companies and innovation laboratories to "oxygenate" the process. Companies aim to profit from their new designs, and they realized that by sharing expertise, intellectual property, and manufacturing methods, they had a larger pool of capabilities that would continually give their own pool of engineers the edge. What really mattered were products that were designed to be "fit for purpose" and a carefully constructed business model that earned satisfactory profits for the consortium of companies as a whole. A front-running example of this occurred in China in the 1980s when the Little Swan Company in Wuxi in Jiangsu Province near Shanghai wanted to produce white-ware because it recognized massive growth potential in China's ever-burgeoning middle-class market. It found that it could not produce a variable speed motor in their washing machine prototypes because their technology and design were insufficiently advanced. And with \$US4.1 million, they bought a working prototype model from Matsushita in Japan, complete with technicians and engineers who immigrated to China on a contract basis. Their job was to train Chinese technicians the process of constructing the kind of home appliance that the Little Swan Company knew they had a ready market for. Once the Chinese engineers mastered Japanese technology, their products became fully functional, and the Little Swan washing machine went through a series of in-house-inspired improvements to the point where the 
company found an export market in the USA and Japan, the homes of quality consciousness. Japanese engineers did not only provide technological and design assistance but also inculcated a new way of thinking and problem solving (Pech et al. 2006).

Likewise, Philips of the Netherlands and Matsushita collaborated through combining technological expertise and funding to invent the first generation of video recorders. These were the pre-digital versions based on celluloid technology but were digitized within 20 years. This industrial combination was a "joint venture" since both sides knew that each only had limited proficiency in their research and a higher level than each could supply individually would be required to produce a machine that could record and re-play television recordings as well as ready-made movies in a front-loaded cartridge. These were multiple advances in one product. In using a shared, later to be called an Open Innovation approach, Philips and Matsushita arrived at a reasonable quality product that made it first to market, ahead of the American venture which aimed to produce the same kind of function. However, the American design could only play back movies and not record directly off TV. And although the reproduction on the screen was a little grainy, being "first to market" in this case was successful even to the point where the better quality "Beta" reproduction system was forced out of the market through clever marketing and customer hire-purchase advantages. Even though that technology has now been advanced significantly, Philips and Matsushita were ahead in their intuition about what such a product should be able to do. They engineered a recording function as well as a film play function; the American version would only have been able to play ready-produce movies but not record for later playback. This is one of the earliest examples of a strategic alliance derived from open innovation, although "open innovation" as a practice has advanced since then. For engineers, there is an important lesson: let the imagination stop at nothing-least of all contemporary technological limitations. Finally, on June 12, 2014, Elon Musk published a statement that stood in strong contrast, "All Our Patents Belong to You". In this, he stated controversially that innovative technologies ought to be and were freely available (http://www.teslamotors.com/blog/all-our-patent-are-belongyou). While not many companies subscribe to this philosophy, it is a boon to engineers, designers, and scientists around the globe because it enhances open-source innovation.

\section{Linking engineering with commercial markets}

Figure 1 demonstrates the inter-relationship between an innovation, its design for the market, and the key steps towards commercializing the new product. It is cyclical because innovations need to be designed and engineered to be commercially viable. Companies often retain a competitive advantage when they re-invest a proportion of their profits to continue being innovative. So in the case of Apple, Inc., this first established the iMac, then the iPod, the iPhone, and then the iPad. The "i" brand continued down the design path of providing enhanced communication. In the case of Macpac, the outdoor company in New Zealand, the design of waterproof outerwear finally became effective through the use of gortex from the USA, manufactured by the Gore Company. These examples demonstrate that innovation needs suitable design for the purpose of commercialization. 


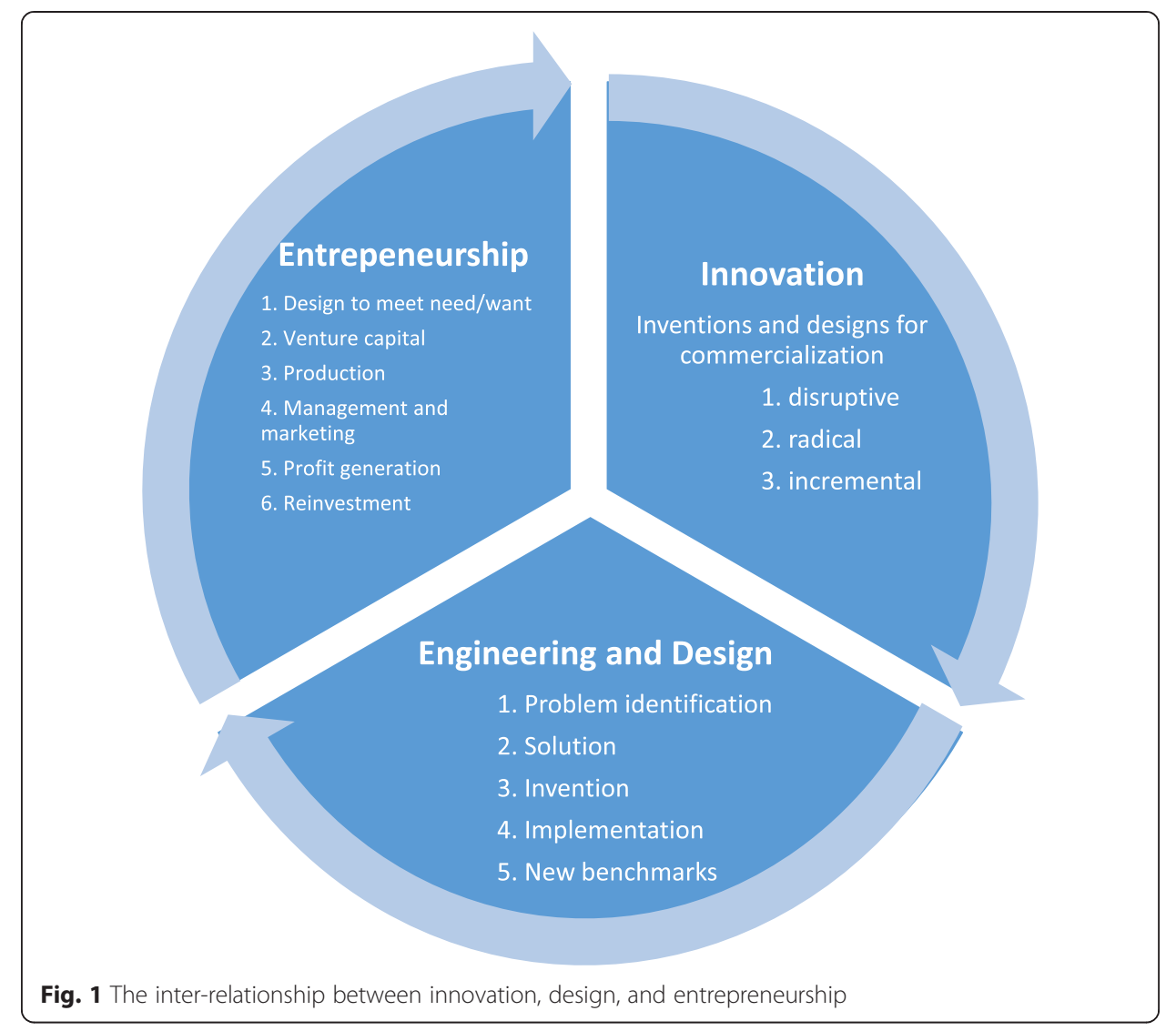

An "innovation" should be distinguished from an "invention" or a "discovery". An innovation has a broader definition than an invention because it implies that this novel item has found, or will eventually find, a place in the commercial market. For many innovators, the transition from the workshop or the laboratory to the market is achieved through the establishment of a new company. The link between engineering and business occurs when innovators believe that they can create a new venture that will commercialize their new product. In their earliest beginnings, large multinationals such as General Electric (GE) and Microsoft were new ventures that produced products which the world of consumers was ready to buy in large quantities once the advantages were proven and well-known.

New ventures are at the core of entrepreneurship. Why are engineering and entrepreneurship such productive partners? Henry Ford succeeded well because he understood the nature of innovation and entrepreneurship. Neither innovation nor entrepreneurship is about "a faster horse," Ford's conclusion about what his customers might want if left to their own imaginations. Instead, when linked hand in hand, we have to understand them as forms of engineering and commerce that naturally combine and generate a market response. In exceptional cases, it may even advance civilization. The telephone, the electric lightbulb, the internal combustion-driven vehicles, and the smart-phone are all engineering items that have had transformational impact. So when Kuratko stated that "Entrepreneurship is the most powerful economic force known to humankind" (2009, p. xviii), it may have seemed an inflated and unrealistic claim. Yet, when you examine entrepreneurship through the last three centuries, epitomized by 
Henry Ford's comment, it seems that Kuratko made an important observation: Entrepreneurship is powerful because it is an aggressive agent of change and therefore an important means of advancement in society. But, entrepreneurship without science and technology is rare and found mainly in service improvements. Even Jeff Bezos' innovative delivery service using drones depends on enhanced drone technology before his service in itself can be enhanced for customers. Disruptive innovation, therefore, can have a proliferating effect.

At times, those innovations, every single one pursued by determined and creative individuals, became significant drivers that impacted on industry, politics, social life, science, and medicine as well as the philosophies and habits governing our behaviors within family life and society as a whole. Innovative design engineering and entrepreneurship as a combination then are a vital aspect of commercial culture.

\section{How did innovative engineers rise above the technological age in which they lived?}

Innovative engineers arise from the age they live in, and yet, they have the distinction of rising above it. Each of the personalities from the 1880s to the current time mentioned in this article provided insights and understanding that advanced existing engineering and then identified a market to take advantage of some basic economic practices. That invariably involved risk. They had to create demand for a new value proposition by marketing it and meeting demand through production processes generating and embedding new supply chains of raw materials. This produces a positive or "multiplier" effect through the economy which endorses Kuratko's earlier comment about it being such a powerful force.

Every one of them also had to devise a new business model to match the product with the market-unless there was an element of inborn genius that could manage to match the product with market demand and produce an instant alignment. Steve Jobs as the CEO of Apple was particularly adept at changing market expectations and demand by means of "i-products" in rapid and steady succession throughout the latter half of his career. Underpinned by his expertise in computer technology, the iPod was not so much a musical device as a handheld computer that stored music digitally and reproduced it; the iPhone was not so much a telephone as another handheld computer that could relay spoken communications. And that same miniaturized digital technology also came to encompass a camera and musical recording capability, with access to commercial broadcasts to the likes of the $\mathrm{BBC}$ and $\mathrm{CNN}$, as well as numerous links to special functions conveniently referred to as "apps". All this in one well-designed appliance, with the promise of more digital feats to follow, such as Uber with customers using smart-phone GPS to locate a taxi in a more convenient and faster method than previously possible. This time, the disruptive effect appears so far-reaching that French taxi drivers have called for a ban on Uber. The smart-phone's capacity to provide services has made it a disruptive technology. More than that, one disruptive technology is often followed by a derivative that is also disruptive. So Apple's compact personal computer replaced IBM's ungainly behemoths thereby disrupting computer functionality through miniaturization, with many flow-on effects such as the disruptions to the 
music industry and the transport industry. Also, consider the impact of Facebook and then Twitter and Snapchat on social networking.

New engineering also provides new services and new methods of product dispersal. Smart-phones are expensive, but to keep costs down, Apple uses outsourcing at Foxconn in China. This necessitates new production, distribution, and costing models. For example, Amar Bose based his company's profits on high margin returns on highest-quality individually crafted instruments of sound reproduction, but Jeff Bezos based Amazon.com on slim margins but extremely high sales volumes. Today, the bricks-and-mortar stores are still in vogue alongside e-retailing on the Internet and each model is suitable as long as the market's quests are met, regardless of the means of sale. In the words of Gary Hamel (2007), "Most of us understand that innovation is enormously important. It's the only insurance against irrelevance. It's the only guarantee of long-term customer loyalty. It's the only strategy for out-performing a dismal economy". And its partner, entrepreneurship, is well described by Richard Branson, "I spend a third of my time promoting, a third on new ventures and a third on fighting fires [...as an entrepreneur] I hope I will never be complacent [...and] if you look for the best in your employees, they'll flourish. If you criticize or look for the worst, they'll shrivel up. We all need lots of watering" (2009, pp. 247-248). Technology and engineering indeed need "watering" to enable them to grow. In the same way that innovation is now open-sourced, management also needs more open sourcing by encouraging divergent opinion. James Surowiecki refers to this as the non-hierarchy model (Jan/Feb. 2015, p. 78).

\section{Characteristics of successful innovative engineers}

Engineers and innovators are essentially "creators" of things. In recent decades, successful innovators in engineering have been associated with prestigious universities. Amazon's Jeff Bezos is a Princeton graduate; Larry Page and Sergei Brin graduated from Stanford but interrupted doctoral studies to start Google. But, Bill Gates and Steve Jobs dwelt on their technological skills and actioned their entrepreneurial inclinations, started university studies but never graduated. Yet, the sound engineer, Amar Bose, naming his company after himself, rarely left his laboratory preferring it to his lecture theater at Harvard where he found vocal students highly disruptive to his thinking and equanimity. And right at the other end of the educational scale, the New Zealand water-jet propulsion engineer, Bill Hamilton, had no technical training at all. He sidestepped academics at his nearest university located in Christchurch, Canterbury University, even though in his day it was, and still is, New Zealand's first-ranked engineering school. Therefore, there is no "rule".

Each engineer recognized that society of the day had an unfulfilled need, and this insight eventually developed into a passion to overcome the limits of the conventional technologies and management practices with which they were familiar up to that point. However, even if the driver of innovative thought did not possess technical training and skill, it was necessary for them to recruit those who did in order to achieve success. Page and Brin would not have succeeded as they did without the input of Marissa Mayer's technical expertise. 


\section{Characteristics typical of successful innovative engineers}

1. Applying a passion for technology and engineering and creating an environment in which that passion becomes a contagion

2. Meticulous, if not obsessive, attention to detail

3. Having an engineering background through formal education to some degree, although the extent of it may vary from sub-undergraduate level to doctoral research level

4. Recognizing that a technological need, or desire, can be filled

5. Filling that need by experimenting with "new" as well as "old" knowledge into novel applications

6. Having a desire to add practice to theory and theory to practice

7. Having little or no concern about interpreting events, situations, and applications in unconventional ways including adopting unconventional ways in which such things are managed

8. Having little or no concern about failure

9. Working with colleagues who have complementary technological skills

10. Creating a vision that focuses on the expanding role of science and engineering in relation to improving the human condition

\section{Disruption as typified by Bill Hewlett (1913-2001) and David Packard (1912-1996) of Hewlett-Packard (HP): innovation and entrepreneurship in action}

Bill Hewlett and David Packard both graduated from Stanford University in electrical engineering. With \$US538 as the capital source for their electrical inventions, they collaborated in a rented garage. There, they created a harmonica tuner, a foul-line indicator, a diathermy machine, and an electric eye. But, their first innovation to impact the market was an audio oscillator which led to contracts with the Walt Disney Company to the point where they had sufficient capital to eventually develop and market the company's first computer, the HP-2116A, no more than an electrical controller tool to measure products. The pace of innovation accelerated. With the company listed on the New York Stock Exchange in 1961, capital enabled them to produce the world's first programmable scientific calculator, and by 1972, the HP lab produced the market's first data processing system, the HP-3000 minicomputer (AlGhotani 2014).

Progress continued apace. In 1982, they began manufacturing the first "handheld" computer that connected drivers and printers, followed by HP's first touchscreen PC. Research and development then continued to arrive at laptops in 1984 and a marked increase in laptops' power boosting in 1991. In the same way, they developed printers as a niche, or specialist market, which became very profitable for the company. From a primitive dot matrix in 1984 to the laser jet, the company had sold 200 million printers globally by 2013. The first color printer entered the market in 1991. The advent of PCs from Apple and other manufacturers played a significant part in the decision to develop printing technology as a byline to HP's original product because it generates a parallel stream of revenue for the company.

In 1950, the company employed 215 people; by 2013, that number had increased to 317,000 which includes the workforce in its off-shore subsidiaries. HP was not only 
innovative in its product development. The company's industrial relations should also be considered; its management was more "open" than conventions of the company's day. Dave Packard devised " 11 simple rules" that formed a contract between the management and employees which emphasized equality, mutual respect, work appreciation, always being involved in attending to detail, mutual understanding, and acceptance, as well as culturing a sincere willingness to collaborate amicably with others. HP was the first company in the USA to introduce flexitime and provided a medical insurance health plan. With an eye on not only recruiting the best candidates for jobs, but also retaining them, HP introduced a profit-sharing plan in 1957 so that all employees with 6 months' service could share in the company's profitability. Thereby, they also enhanced employee motivation to achieve greater innovation and productivity. Dave Packard is quoted as saying, "Investing in new product development and expanding the product catalog are the most difficult things to do in hard times, and also among the most important" (https://www.linkedin.com/grp/post/255687688153116). HP was disruptive not only in its technological advancements but also in its management systems, frontrunners for the liberal, non-hierarchical ways in which Google and Apple deal with their employees' creative inclinations.

\section{Characteristics of successful entrepreneurs in the field of engineering}

Bygrave and Zacharakis believe there are ten "Ds" that characterize successful entrepreneurs: dreams, decisiveness, doers, determination, dedication, devotion, details, destiny, dollars, and distribution (2008, p. 53). From the sampling of entrepreneurs in this article, recounting only those characteristics is no longer sufficient. Apart from the ten "Ds," we could add several other characteristics that have been demonstrated throughout these cases spanning the last 150 years: ingenuity, integrity, adaptability, self-discipline, and their aspirations to facing challenges as a means of expressing themselves as unique individuals. From the nineteenth century of Alfred Nobel to Marissa Mayer in the present, we witness an evolution in which women become more prominent, but the key spirit of engineering innovation and entrepreneurship remains much the same regardless of gender.

Entrepreneurship is often associated with the accumulation of personal wealth-indeed greed. There are latent overtures here of Wall Street. Bygrave and Zacharakis (2008), p. 3, remind us that "The most common reason for wanting to start a business is to increase one's personal income (66\% respondents), followed by increased independence (63\%)". However, it is significant to note that an aspect of the engineers that has been selected here is commitment to work, as this envisions the greater good that might be achieved rather than the wealth generated only for an individual. In many cases, it would be naïve to deny that. But, the quality that distinguishes some innovators is that they wanted to create something that would give them a place in history, even if it were only a minor place. Their devotion towards achievement in each case was something they valued more than their notion of the wealth it might bring them. In the words of John Sculley, Steve Jobs' collaborator (as well as nemesis), "I'd say, find a noble cause. When I spent time with Bill Gates or Steve Jobs we never talked about making money; we talked about noble causes. Their noble cause was to make computers personal, empower knowledge workers with incredible tools for the mind and try to change the world one person at a time. So my advice to an entrepreneur is to find a noble cause" (Raj 2014 October 10). 


\section{The vital roles of technology and design}

One of the prime concerns that technologists have is that their innovation is a means of increasing the quality of life-the ease, comfort, and safety of daily activities and prolonging security and life itself-and in many cases the enjoyment of life. A number of key figures have made contributions that may rightfully claim to have changed the world. Usually for the better, although at times, there were those who experienced unexpected negative consequences too. The Swede Alfred Nobel in the 1860s, for example, devised an explosive that was safe to handle for the purpose of better exploiting minerals, such as coal to fuel the Industrial Revolution. It was a 3:1 mixture of nitroglycerin and a clay-like substance called kieselguhr. By 1873, he owned 16 dynamite factories in 18 countries and through extreme diligence through correspondence in no fewer than six languages, he managed each of them. And then by the 1880s, he stood aghast in his later years to discover that his innovation, a dry and portable explosive he called "dynamite," could equally be deployed to advance nations politically through inflicting death and war with an efficiency that war had never experienced before. $\mathrm{He}$ became reclusive in the last decade of his life and left his huge fortune to his household servants and the larger portion to a prize in his name that would celebrate scientific achievement, specifically medicine, physics, chemistry, literature, and ostensibly, peace. (Economics was added later by the banking fraternity.) Peace and excellence in human achievement became his vision for the future of human endeavor, in contrast to the destruction which his invention had inadvertently fueled. From accounts of his time, there are those who believe that Nobel died in 1896, in a state of what we would today might call "depression".

American Howard Hughes (1905-1976) was an engineer of equal genius, and died an equally reclusive death. Having dabbled in Hollywood's earliest moving pictures, he turned his attention to aircraft engineering. The H-4 Hercules, better known as the "Spruce Goose" was five stories tall and had a wingspan that exceeded the length of an American football field (http://www.theaviationzone.com/factsheets/hk1_specs.asp). Launching it in 1948, Hughes designed it to carry 750 fully equipped troops or two Sherman tanks over long distances. But, it flew for only $1.6 \mathrm{~km}$. Spruce Goose was a feat of engineering which exemplified significant truths about innovation and entrepreneurship. Firstly, all innovations comprise an advancement on their predecessors, if indeed there were predecessors, but there comes a point when the technology of the day reaches a point of stasis. This is because an innovation may get bigger or faster and even cheaper than its predecessors, but prior to real advancement, it must await a breakthrough or "radical" innovation in its technology to progress to the next level. This will advance it to the point where a new "dominant" model comes into being. For instance, Hughes' Spruce Goose was a gigantic craft with eight turbo propellers and was the greatest of a generation of aircraft in which the means of propulsion had hitherto been successful. Hughes' design was innovative in that it was purposed to achieve sea takeoff and landings with the largest number of passengers achievable in its day. But, the inadequacy of his design was responsible for its propellers, its aged means of propulsion, exceeding the weight to power ratio of the aircraft. This meant that it could not adequately achieve sustainable lift and forward motion at the same time. Spruce Goose was constructed with heavy metals and was under-powered. It took a new design, the thrust capabilities of the jet engine, to achieve new dominance in 
aeronautics-the new "dominant model" (Utterback 1994). Hughes is now rarely remembered for one contribution to aerodynamics that indeed showed his genius instead of his failure: he was the first engineer to realize the friction caused by rivet construction, and so, he concealed them to effect better airflow over his aircraft fuselage and wings (Krayem 2014).

A number of aviation engineers have been credited with the breakthrough of air propulsion from turbo-prop to jet-a revolutionary design. But, Kelly Johnson, the American aeronautics engineer, contributed more greatly than any of his predecessors because his "Blackbird" supersonic spy plane was a unique outcome of the need for speed, height, and safety. This would become the forerunner of passenger air travel in our age, which is almost exclusively by jet propulsion. Kelly Johnson invented the "skunk work" practice in which technical innovations are constructed in specially equipped laboratories and workplaces with their own budget. He worked during the Cold War between the USA and the then Soviet Union and was commissioned to build a plane that could fly on Mach 3 at an altitude of $80,000 \mathrm{ft}$ in order to avoid Soviet radar systems. Saeed and Sebastien (2014) noted that flying at such an unprecedented speed and height necessitated the development of new designs in aerodynamics, special fuels that would not freeze or coagulate in severe sub-zero temperatures, new structural materials, and manufacturing tools and techniques, as well as unfamiliar hydraulic fluids, fuel tank sealants, protective paints that had the necessary elasticity when stretched by extraordinary speeds, hard and soft plastics, and new conducting materials in wiring technology.

Blackbird's fuselage was made of titanium. This was a metallic material that Johnson had experimented with for many years. Ironically, the Central Intelligence Agency had to create several cover-up, or "dummy" companies, in order to purchase titanium for the construction of the 12 Blackbirds it had commissioned from Johnson. The titanium had to come from Soviet Russia, the very country that they wanted to spy on.

The SR-71 Blackbirds flew at $2193 \mathrm{mph}$, and at 85,069 ft, being able to complete flights from New York to London in $1 \mathrm{~h}$ and $44 \mathrm{~min}$, thereby adding these accomplishments to the engineering that inspired Concorde, the supersonic passenger aircraft manufactured by a consortium of British Airways and Air France in the 1970s.

\section{Not succeeding according to plan}

Engineers and scientists often pursue knowledge in order to know the "unknowable". There are times when its ultimate purpose does not appear to have either a scientific or commercial context. The future is characterized by a "fuzziness" in which an invention or design does not yet have a concrete function or place. And so, there is a mystique to the discovery: what is its significance? This means that there may or may not be a larger plan or purpose. And if there is, it may not succeed. Did Marie and Pierre Curie grasp the significance of radium, other than that they realized they had discovered another element to add to the periodic table? Roentgen was so puzzled by the potential of the radiation instrument he invented that he called his ray by the variable "X," the unknown quantity, because while the X-ray penetrated human flesh, it did not immediately penetrate Roentgen's consciousness that his invention could significantly contribute to orthopedic and other forms of medicine. 
Not succeeding according to plan, if there is one, seems an integral part of innovation and entrepreneurship. Yet, another integral aspect is that if innovators and entrepreneurs were to be deterred by failure, it would eventually preclude all possibility of success for future implementation. At times, this meant that the genius of the individual had to be compromised through the mutual benefits of partnering with someone else, maybe with complementary talents or with access to financial resources. But, what mattered most was that this partnership had to comprise men and women of like mind technologically speaking and of equal determination to succeed. Karl Benz's financial problems in the development of his internal combustion engine in the 1880s saw him having to partner with Gottlieb Daimler and Wilhelm Maybach to re-kindle his dream of a commercial "autowagen". Today, the Mercedes-Benz flagship is not called the S600 but the "Maybach". Similarly, Sergei Brin partnered with Larry Page in a working relationship eventually arriving at an algorithm that led to the "search engine". The concept of the search engine was not new, but theirs was the best design. Soon, another employee who became a partner, Marissa Mayer, assisted them in their software advancement that led to commercial success. This was akin to Hewlett and Packard's computer hard- and software collaboration. And eventually in the Netherlands, Dr. Willem Kolff invented the first dialysis machine for the treatment of kidney impairment, but he later conceded its commercial success to Nils Alwall whose machine was a technological improvement on his own. Not succeeding according to plan then often necessitated innovators and entrepreneurs inclining towards a different form of commercialization than they originally intended. A vital part of an entrepreneur's creativity is adaptability.

"Adaptability" to some meant steering towards miraculous innovation and away from the world of commerce at the same time. There were those, like Dr. Willem Kolff, who felt that commercialization for his own financial reward was inappropriate in the first place because he believed it to be inconsistent with his medical ethics which signified medical salvation not wealth. As such, he may be counted as one of the first "social entrepreneurs"-men and women who believe in placing the needs of society before their own (Bessant and Tidd 2011). Kolff felt that taking pecuniary advantage of the sick was inappropriate and when he donated the first five of his machines to hospitals which were in his opinion most likely to avail themselves of the new medical opportunity, it was testimony to his philanthropic vision.

\section{Companies and their evolution}

Innovation and entrepreneurship are very diverse undertakings but are inextricably bound together. They are as individual as the personalities who drive it. Most of all, it is a form of self-expression, a means for people to obtain a more effective way to control their own life's destiny and those of others. More than that, their expression of the "self" impacts the world.

The challenge is to keep innovation as a pursuit as well as companies that have derived from it evolving with other technological advances as well as the markets. Arie De Geus (1999) maintained that all companies should be understood as living beings or organisms that should grow as they literally do in their natural environments. If this analogy has efficacy, it means that companies develop by changing to meet the needs of their market. Those which accomplish this with the greatest efficiency are most likely 
to thrive. At times, this means that companies have to take drastic action to discontinue or modify their customary work cultures. In October 2014, Hewlett-Packard under CEO Meg Whitman revealed that the company structure was to be changed by splitting into two divisions, one focusing on PCs and the other one on printers. A serious cost-reduction program would also entail thousands of redundancies; Waters and Mishkin reported that 16,000 jobs were eliminated in May 2014 and that the total number of forecast job cuts might go to 50,000 (Financial Times). The expectation is that this will make the company more competitive because a company must at least survive if circumstances do not allow it to thrive. This is the result of the growth of other computer companies in the field like Lenovo of China, which are smaller, still at an earlier stage of entrepreneurial development, and this placement on the company longevity curve has a tendency to make them more nimble and adapt to technological advancement more quickly. Without a change in production strategies, HewlettPackard could find itself outmaneuvered by smaller more nimble companies or companies that can innovate faster.

While this is happening with Hewlett-Packard, Jeff Bezos of Amazon is considering alternatives as well. He has come to believe that online retailing may have its disadvantages as well as the very advantages on which he originally based his company. The word is that Amazon may open its first physical, that is, bricks and mortar, retail outlet in 34th Street, in Manhattan, NY, to cater for those customers who avoid the "select and click" method and who prefer to handle the merchandise before they make up their minds to buy (Shan 2014).

Both companies are good examples of De Geus' theory, and companies must be nurtured and cultivated to continue to "live". In these cases, one industrial computer giant goes from being a large monolith towards fragmentation, and another goes from being an online giant to a physical retail address to enhance the shopping experience to capture a greater market because retail psychologies vary from customer to customer. It may be a new direction to in addition to the older one to offset the impact of Alibaba, the e-commerce giant of China which launched its IPO on Wall Street early in 2015. Yet, markets notwithstanding, each company at its core has the technological excellence without which it could not survive in the first place, let alone thrive. Therefore, there can be no doubt that innovation is an ongoing, iterative process. A "one-hit-wonder" like the pet-rock cannot succeed for long.

\section{Managing and implementing innovation}

When Eric Schmidt was first appointed as CEO of Google, little did he understand the company's innovative culture. He had good reason to believe from his experience in previous companies that his new standing in Google would give him the company's most important voice. Hamel (2007) provides us with insights about an important aspect of Google's inner workings: There is little hierarchy and priority is given to good ideas-regardless of the status of the employee who raised it. The collaborative ethos denies the CEO automatic rights of always making unilateral strategic decisions. Engineers of whatever technological denomination have considerable freedom to join teams which collaborate on new means of progress, which in the past has led to Google Earth, Gmail, and Google Scholar, just three of about 150 products and services the 
company now has on offer. Engineers' areas of expertise are carefully considered to be complementary, not for the purpose of social harmony but so that advances can be debated by the most informed means by the most informed employees in the company. So in respect of company authority, what is Schmidt's role? It is to pursue dialogue with the company's most innovative engineers and team leaders to arrive at judgments concerning a new project's viability and to what extent he should authorize funding. His responsibility in this respect is tangential to the more conventional ones in his former occupations. Not only are Google's products innovative but also Page and Brin realized that they had to create a company culture to match.

On the other hand, while not all companies advance their goals based on high techelectronics and software like Google, Apple, Huawei, and Samsung, they must still focus on the uniqueness of their engineering prowess. A company that typifies the manufacturing side of such prowess is Rip Curl, the Australian surfing company. It has been engineering improvements in water-sports products for half a century. In the history of this company, no person has ever been employed who was not a surfer and intensely passionate about the sport. Primarily known for their world-leading wet-suit technology, the company's founders Doug Warbrick and Brian Singer first intended a crude rubber suit to do no more than keep surfers from hypothermia in the frigid winter waters off the coast of Bell's Beach on the Victorian coast south-west of Melbourne. Their skin-tight suits disrupted those manufactured by those of O'Neill which were loosefitting. But, their early suits had a design flaw: ordinary everyday over-the-counter rubber sewn together as a body suit has nodal points where the thickness under the arms and between the legs impedes movement and that in turn impedes the balancing act on a surfboard. This recognition resulted in the dual-density wet suit where the rubber in those pivotal locations is half the thickness of the rest of the body to allow for free movement. Since the company's formation in 1969, its founders' aim has been to reduce the overall thickness and to increase its warmth-retention effectiveness at the same time, with designs in suits inspired by their employees from the bottom-up. So, its uniqueness is in the scientific advances it has made in collaboration with synthetic fabric engineers to improve the quality of wet-suit materials. During the last 50 years, the materials began with conventional rubber and progressed to Elastomax with color mesh, a design comprising a fraction of the original thickness and increasing flexibility and warmth manyfold (Pech 2002).

And so, in the case of both companies, success was due to the emphasis on improving the engineering as well as opening the management approach. In the case of Kelly Johnson, it has been discussed in an earlier section that rapid improvement to air surveillance might mean the difference between winning or losing the Cold War-in the mode of thinking at the time. The Skunk Works that he created was not only for unique workshop and tooling purposes but also vital for the project's secrecy as well as distancing his crew from conventional thinking about flight. If he had stayed with the same technologies, he would not be able to make advances. He needed a point of separation. The same held true for the New York Times when it first considered digitizing the news. Company supporters, including journalists and editors, experts in the field of traditional print, entered into emotional crescendos of nervousness, suspicion, and feeling threatened when they perceived that a new technology such as Internet publishing would displace them. As a result of the politics that ensued, the digital faction separated itself physically altogether so that it could concentrate on perfecting the methods and displays on the computer screen 
instead of the printed page. Eventually, both technologies were to exist in a symbiotic relationship that simply caters for readers with different preferences.

\section{Implementing innovation}

There is no "one way" in which innovators succeed, but they seem to have a number of characteristics in common:

1. Innovators learn from each other, not only in their immediate industrial and scientific neighborhoods but also from all parts of the world where science makes advances and is released for public consumption.

2. Innovators strive to remain up-to-date with all forms of engineering progress to incorporate advancing technologies and materials into their own thinking and intuitions and eventually their products (in as far as patents, copyrights, and licenses allow).

3. Closed innovation has given way to open-source innovation because sole geniuses are rare and collaborative efforts are more productive. Those, like Elon Musk, still require the assistance, support, and the critiques of others, in scientific and market situations that are becoming too complex for one person to control or even operate in.

4. Education in technology and engineering has a bearing on the likely success of an innovative product; however, the level of education is not immediately indicative of the likelihood of success.

5. Engineers make most progress when they possess and can share a passion for their field with others whom they can turn into collaborators or partners-local or international.

\section{The future}

It is evident from the theory and examples that have been provided that likely the present trends in disruptive technological impact on entrepreneurship in particular and business in general can be extrapolated. This extrapolation refers to many fields because as we have already observed, there is a proliferating effect of geometric expansion as one technological breakthrough catalyzes another. The trend is towards smaller, further, faster, and cheaper-the definitive features of disruption. It refers to space tourism, 3-D printing, and miniaturization. To take just one example that is close on the horizon, sensors, processors, and actuators will become so advanced that a criteriabased decision process in any system is enhanced by diminishing the response time. For example, it may intervene to brake a fast-moving vehicle by responding to traction changes depending on different road surfaces to within 5-10 ms for the safety of the driver. At the present time, such a response time does not yet exist. However, it is anticipated and will disrupt the processor and actuator markets when it is achieved.

\section{Conclusions}

Innovation, technology, design, and entrepreneurship go hand in hand. One disruptive innovation can initiate more. This kind of innovation can stimulate wealth as well as contribute to the public good. It has been demonstrated again and again during the last one and a half centuries that there is a line of progress in which new ideas, particularly disruptive ideas, can lead to fundamental changes in products and services upon which 
commercial markets thrive. However, for innovation, especially the disruptive kind, to flourish it, it must be freed from the shackles of conventional management and thinking patterns which have a tendency through their very nature to inhibit it. Introducing more tertiary courses that exemplify successful couplings between innovation, design, and entrepreneurship is an aspect of a new thinking pattern to shift away from the conventional.

\section{Methods}

Technological and managerial advancements play crucial and vital roles in successful innovation and hence entrepreneurship. The data referred to comprises a diverse collection from secondary sources as well as primary sources that explain the innovator/ design/entrepreneur cycle. The data from Little Swan Industries of China, Rip Curl of Australia, and Macpac of New Zealand are the outcome of a qualitative case study investigation conducted by the author himself.

Secondary data were then collected from a wide variety of sources that covered a period of over 100 years. These data focused on patterns of disruptive innovation and how they influenced the commercial market. The examples derived from the data exemplify the role played by technology, design, and management practice in the widest sense, including marketing and retailing.

Furthermore, the content of this article is the product of intensive research undertaken to establish and implement a tertiary course in innovation and entrepreneurship. This undergraduate course is about to become mandatory in all universities in the United Arab Emirates (UAE) from the Fall Semester in 2016. As the two disciplines of innovation and entrepreneurship develop further through education, development, and training, practice will continue to be informed by theory and theory by practice. The introduction of this business course will affect over 120 institutions and almost 130,000 students in its first iteration alone. In conjunction with Stanford University in the USA, the Ministry of Higher Education in the UAE has expressed its desire that an innovation and entrepreneurship course will act as an encouragement to create "a solid social, scientific and knowledge culture for university students, so as to be adopted as a future vision and approach that supports the government's efforts in building a knowledge-based economy when these students become leaders and entrepreneurs within a few years" (mohesr.gov.ae 28 Dec. 2015). Likewise, all practitioners may be described as "students" of innovation and entrepreneurship as the search for technology and markets continues.

Competing interests

The author declares that he has no competing interests.

\footnotetext{
Authors' information

Dr. R.M. Pech is Assistant Professor in Management at Khalifa University of Science, Technology and Research in Abu Dhabi in the United Arab Emirates. His PhD is in innovation management from the Royal Melbourne Institute of Technology. His teaching and research focus on the developments in innovation and entrepreneurship.
} 
Branson, R. (2009). Screw it, let's do it-lessons in life and business. London: Virgin Books.

Bygrave, W., \& Zacharakis, A. (2008). Entrepreneurship. Chichester: Wiley and Sons.

Chesbrough, H. (2003). Open innovation: the new imperative for creating and profiting from technology. Boston: HBSP. Christensen, C., \& Raynor, M. (2003). The innovator's solution-creating and sustaining successful growth. Boston: HBSP. Cowden, B. \& Alhorr, H. (2013), Disruptive innovation in multinational enterprises, Multinational Business Review, 21(4), 358-371.

De Geus, A. (1999). The living company: growth, learning and longevity in business. London: Nicholas Brealey Publishing Denning, P., \& Dunham, R. (2010). The innovator's way-essential practices for successful innovation. Boston: MIT Press.

Dyer, J., Gregersen, H., \& Christensen, C. (2009). The innovator's DNA. Harvard Business Review, accessed 21 December 2015 at http://hbr.org/2009/12/the-innovators-dna/sb2

Hamel, G. (2007). The future of management. Boston: HBSP.

Hang, C., Chen, J., \& Yu, D. (2011). An assessment framework for disruptive innovation. Foresight, 13(4), 4-13.

http://mohesr.gov.ae Accessed 28 December 2015.

http://www.brainyquote.com/quotes/authors/g/gary_hamel.html. Accessed 1 June 2015.

http://www.livescience.com/45992-elon-musk-innovations.html. Accessed 3 June 2015.

http://www.teslamotors.com/blog/all-our-patent-are-belong-you. Accessed 4 June 2015.

http://www.theaviationzone.com/factsheets/hk1_specs.asp. Accessed 2 June 2015.

https://www.linkedin.com/grp/post/2556876-88153116. Accessed 1 June 2015

Kaplan, S. (2012). "Leading disruptive innovation," Ivey Business Journal at http://iveybusinessjournal.com/publication/ leading-disruptive-innovation/ Accessed 3 June 2015.

Krayem, B. (2014). Howard Hughes (1905-1976), tycoon in motion pictures, aviation and aeronautics. In R. Pech (Ed.), Great innovators and their legacies: Inspiring feats of engineering and their impact on consumer markets. Saarbrucken: Lambert Academic Publishing.

Kuratko, D, (2009). Introduction to entrepreneurship. $8^{\text {th }}$ Ed, Boston, Mass: Cengage Learning.

Leavy, B., \& Sterling, J. (2010). Think disruptive! How to manage in a new era of innovation. Strategy \& Leadership, 38(4), 5-10. Mazzucato, M. (2015). "The innovative state," in Foreign Affairs - Special Entrepreneurship Edition. 94, 1, 61-68.

Packard, D, quoted in http://www.forbes.com/sites/philmckinney/2011/10/03/10-quotes-from-bill-hewlett-and-davidpackard-that-every-executive-should-read/\#24fdbd2b231c Accessed 3 June 2015.

Pech, R. M. (2002). Rip curl: Making waves of their own. In R. J. Pech (Ed.), Making waves, innovation in business (pp. 114-125). Sydney: Prentice-Hall.

Pech, R. M., Pech, R. J., Wei, D. \& Shi, H. (2005), Innovation through acquisition: the Jiangsu Little Swan Group Company in the People's Republic of China, European Journal of Innovation Management, 8(1), 107-119.

Raj, A. (2014). The billion dollar man. Abu Dhabi: Friday in Gulf News.

Saeed, A., \& Sebastien, D. (2014). Kelly Johnson (1910-1990) pioneer in jet propulsion. In R. M. Pech (Ed.), Great innovators and their legacies: Inspiring feats of engineering and their impact on consumer markets. Saarbrucken: Lambert Academic Publishing.

Sajwani, S. (2014). Alfred Nobel (1833-1896) inventor of dynamite and founder of the Nobel Prize. In R. M. Pech (Ed.), Great innovators and their legacies: Inspiring feats of engineering and their impact on consumer markets. Saarbrucken: Lambert Academic Publishing.

Shan L, Los Angeles Times, syndicated in Gulf News, (2014, October 11), Section B1.

Shapiro, G. (2013). Ninja innovation - the ten killer strategies of the world's most successful businesses. New York: HarperCollins.

Surowiecki, J. (2015). "Thinkers and tinkerers". Foreign Affairs - Special Entrepreneurship Edition, 94, 1, 77-83.

Tesar, D. (2015). "Summary of the next wave of technology," in Mechanical Engineering, 9, 137, 1-2.

Utterback, J. (1994). Mastering the dynamics of innovation: how companies can seize opportunities in the face of technological change. Boston: HBSP.

Waters, R, and Mishkin, S. (2014). "HP to spin off PC and printer unit," Financial Times, syndicated in Gulf News, Section B5.

\section{Submit your manuscript to a SpringerOpen ${ }^{\circ}$} journal and benefit from:

- Convenient online submission

- Rigorous peer review

- Immediate publication on acceptance

- Open access: articles freely available online

- High visibility within the field

- Retaining the copyright to your article

Submit your next manuscript at $>$ springeropen.com 